\title{
LITERATURE REVIEW: KORELASI PANJANG TULANG EKSTREMITAS DENGAN TINGGI BADAN DALAM IDENTIFIKASI FORENSIK
}

\author{
Satria Saputra ${ }^{1}$, Angeline Novia Toemon ${ }^{2}$, dan Ricka Brillianty Zaluchu ${ }^{3 *}$ \\ ${ }^{1}$ Program Studi Pendidikan Dokter, Fakultas Kedokteran, Universitas Palangka \\ Raya, Kalimantan Tengah, Indonesia \\ Email: saputrasatria07@gmail.com \\ ${ }^{2}$ Departemen Histologi, Fakultas Kedokteran, Universitas Palangka Raya, \\ Kalimantan Tengah, Indonesia \\ Email: angeline_toemon@med.upr.ac.id \\ ${ }^{3}$ Instalasi Kedokteran Forensik, RSUD dr. Doris Sylvanus, Palangka Raya, \\ Kalimantan Tengah, Indonesia \\ Email: brilliantyricka@gmail.com
}

\begin{abstract}
ABSTRAK
Pengukuran panjang tulang ekstremitas dalam identifikasi forensik dapat digunakan dalam menentukan identitas personal, salah satunya tinggi badan. Beberapa penelitian telah dilakukan untuk menghasilkan rumus regresi yang sifatnya prediktif, namun setiap rumus memiliki hasil yang berbeda, terdapat selisih nilai akhir dalam memprediksi tinggi badan seseorang, hingga perbedaan metode pengukuran. Penelitian ini bertujuan untuk menganalisis korelasi antara panjang tulang ekstremitas dengan tinggi badan, metode pengukuran, perbedaan hasil akhir, hingga mengetahui bagian tulang ekstremitas yang memiliki korelasi paling kuat. Penelusuran artikel dilakukan melalui google scholar dan sciencedirect.com dengan menggunakan kata kunci panjang tulang ekstremitas dan tinggi badan, kemudian sebanyak 25 artikel yang memenuhi kriteria inklusi dilakukan review. Dari hasil penelitian pada ekstremitas atas, 10 dari 17 artikel menunjukkan korelasi antara lengan bawah/tulang radius dan ulna terhadap tinggi badan (58,8\%), 5 artikel pada lengan atas/tulang humerus $(29,4 \%)$, dan 2 artikel pada panjang tangan (11,8\%). Pada ekstremitas bawah, 4 dari 9 artikel menunjukkan korelasi kuat antara tulang tibia dan fibula terhadap tinggi badan (44,5\%), 3 artikel pada tulang femur $(33,3 \%)$, dan 2 artikel pada panjang kaki (22,2\%). Berdasarkan metode pengukuruan, 24 artikel (96\%) menggunakan pengukuran secara perkutaneus, dan hanya 1 artikel (4\%) yang menggunakan metode Post-Mortem Computed Tomography (PMCT). Penelitian ini menyimpulkan bahwa semua komponen tulang ekstremitas memiliki korelasi yang bermakna terhadap tinggi badan, walaupun dengan besar kekuatan korelasi yang beraneka ragam. Metode pengukuran terbaik adalah secara perkutaneus untuk menghindari potensi bias pada metode imaging/pencitraan.
\end{abstract}

Kata Kunci: panjang tulang ekstremitas, tinggi badan

\begin{abstract}
The measurement of extremity bones length in forensic identification can be used to determine the personal identity, one of which is the stature. Several studies have been conducted to generate predictive regression formula, yet, each formula resulted different number of one's stature including various methods of its measurement. This research aims to analyze the correlation between extremity bones length with stature, measurement methods, final result deviation, and which part of extremity bones has the strongest correlations. The articles were searched and collected from Google scholar and Sciencedirect.com by entering "extremity bone length and stature" as the keywords in which 25 qualified articles were reviewed based on the inclusion criteria under this research. In terms of upper extremity, 10 of 17 articles revealed a correlation between forearm/radius and ulna bone with the stature (58.8\%), 5 articles in upper arm/humerus bone $(29,4 \%)$, and 2 articles in hand
\end{abstract}


length $(11,8)$. Meanwhile, in lower extremity, 4 of 9 articles showed a strong correlation between tibia and fibula bone with stature (44,5\%), 3 articles in femur bone $(33,3 \%)$, and 2 articles in foot length $(22,2 \%)$. Based on the measurement methods, 24 articles (96\%) used percutaneus measurement, and only 1 article (4\%) used post-mortem computed tomography (PMCT). This research concluded that all the components of extremity bones length have a significant correlation with stature, although its correlation is various. The best method is percutaneus measurement to avoid the potential bias occurred in imaging method.

Keywords: extremity bone length, stature

\section{PENDAHULUAN}

United Nations Office on Drugs and Crime (UNODC) menyatakan bahwa tindakan kriminal menyebabkan lebih banyak kematian dibandingkan gabungan antara kasus konflik dan terorisme, tercatat sebanyak $\quad 464.000 \quad$ korban pembunuhan yang jauh melampaui jumlah korban kasus konflik bersenjata sebanyak 89.000 dan korban terorisme sebanyak 26.000 pada sepanjang tahun 2017.[1] Badan Pusat Statistik (BPS) pada tahun 2017 juga mencatat bahwa dari tiap 100.000 orang yang berada di Indonesia, 129 orang diantaranya menjadi korban tindak kejahatan (Crime rate) dengan interval atau selang waktu kejadian suatu tindak kejahatan/kriminal (Crime clock) adalah 1 menit 33 detik (00.01'33') dalam jumlah kejadian kejahatan (Crime total) sebanyak 336.652 kasus dan diantaranya terdapat kejadian kejahatan terhadap nyawa 1.150 kasus (jumlah banyaknya kasus kejadian tidaklah menggambarkan berapa jumlah banyaknya korban karena pada satu kejadian tindak kejahatan bisa jadi lebih dari satu orang korban).[2] Termasuk didalamnya kasus pembunuhan disertai dengan mutilasi. Pada tahun 2017 di Provinsi Kalimantan Tengah terdapat 2621 kasus Tindak Pidana dan 30 kasus diantaranya berakhir dengan pembunuhan.[3]

Identifikasi dalam disiplin ilmu kedokteran forensik merupakan salah satu upaya dalam membantu penyidik untuk mengetahui, menentukan, dan menemukan identitas asli seseorang, hal ini amat krusial dalam proses penyidikan karena seandainya terdapat kesalahan akan dapat memengaruhi hasil akhir dalam suatu proses peradilan.[4] Setiap proses identifikasi yang dilakukan terhadap korban kasus mutilasi memerlukan beberapa data pendukung, namun biasanya terdapat keterbatasan data dikarenakan penemuan beberapa potongan tubuh yang tidak menentu secara terpisah, tidak berada dalam satu tempat yang sama. Peran ilmu kedokteran forensik dalam mengidentifikasi dan membantu penyidik untuk menentukan identitas jenazah yang sudah rusak, asing/tidak dikenal, sudah membusuk, jenazah korban mutilasi maupun jenazah dengan sebab kematian karena bencana alam, kebakaran, insiden kecelakaan massal, dan ledakan bom. Proses identifikasi dengan standar prosedur lain yang dapat dilakukan, namun terdapat kesulitan dan keterbatasan jika keadaan jenazah korban yang sudah rusak dan tersegmentasi menjadi beberapa potongan tubuh. Sehingga salah satu 
alternatif bila potongan tubuh jenazah tersebut ditemukan, dapat digunakan sebagai salah satu parameter dalam mengestimasi tinggi badan dan bentuk perawakan melalui panjang komponen tulang ekstremitas.

Identitas dari seseorang baru bisa dengan yakin dipastikan jika diketahui minimum terdapat dua metode yang dipakai menunjukkan hasil pemeriksaan yang valid dan tidak meragukan lagi. Ilmu antropologi forensik merupakan satu dari beberapa bagian disiplin ilmu yang menunjang proses pelayanan kedokteran spesialisasi forensik medikolegal dengan berdasarkan pada kapasitas dan kapabilitas dalam analisis antropologis guna merekonstruksi dan memvisualisasikan gambaran sketsa biologis seorang individu yang tidak dikenal dalam rentang/jangkauan masa lampau hingga sampai saat ini. Banyak informasi yang akan diperoleh dari hasil identifikasi, selain bermanfaat untuk kemanusiaan juga bermanfaat untuk kasus-kasus kematian yang disebabkan tindak pidana ataupun kriminalitas.[4] Identifikasi dapat diaplikasikan dalam beberapa cara dan metode, salah satu diantaranya yaitu dengan menentukan tinggi badan seseorang.

Tinggi badan adalah salah satu indikator dan parameter yang sangat esensial dari data big fours atau empat data profil biologis penting selain jenis kelamin, usia, dan ras seseorang dalam ilmu antropologi forensik maupun praktik medikolegal untuk kepentingan pendataan dan penyelidikan, bahkan terdapat kolom isian khusus pada lembar formulir identifikasi korban (victim identification form). Seseorang memiliki ukuran tinggi badan yang beragam dan bervariasi antara satu dengan yang lain. Terdapat pelbagai faktor yang mampu memengaruhi ukuran tinggi badan seseorang, yakni diantaranya adalah genetik, asupan nutrisi, ras, jenis kelamin, aktivitas fisik serta lingkungan. Usia ideal untuk melakukan pengukuran tinggi badan adalah sebelum usia 25 tahun, karena usia diatas 25 tahun manusia mengalami pengurangan tulang sekitar $1 \mathrm{~mm}$ pertahunnya.[5] Secara sederhana tinggi badan manusia dapat diukur menggunakan metode anatomis, yaitu dari vertex (atas puncak kepala) hingga ke bagian terbawah plantar pedis (telapak kaki), kemudian dilakukan pengukuran untuk menentukan panjangnya.[6] Disamping itu terdapat metode rekonstruksi alternatif yang dapat pula digunakan untuk mengestimasi ukuran tinggi badan seseorang, yaitu dengan metode matematis untuk menunjang identifikasi pada keadaan tertentu. Metode ini dapat mengetahui ukuran tinggi badan hanya dengan mengukur panjang satu tulang atau bagian tubuh tertentu dengan menggunakan rumus regresi.[7]

Beberapa penelitian telah dilakukan guna melihat korelasi antara panjang komponen tulang ekstremitas dengan tinggi badan dan menghasilkan beberapa rumus regresi yang sifatnya prediktif, diantaranya adalah tulang humerus, radius, ulna, femur, fibula, hingga tibia.[8] Namun setiap jenis rumus tersebut masih 
memiliki hasil yang berbeda antara rumus satu dengan yang lainnya, masih terdapat selisih nilai akhir dalam memprediksi tinggi badan seseorang. Kemudian adanya perbedaan dalam melakukan penelitian sebelumnya, sebagian besar menggunakan metode pengukuran secara perkutaneus, dan sedangkan sebagian kecil menggunakan metode Computed Tomography (CT) yang mengarah pada otopsi virtual menggunakan teknologi, akibatnya banyak hal yang memengaruhi dan dipengaruhi dari perbedaan tersebut. Hingga saat ini, tinjauan literatur secara sistematis mengenai korelasi panjang tulang ekstremitas dengan tinggi badan belum pernah dilakukan sama sekali, sehingga belum diketahui penyebab mengapa perbedaan hasil akhir dari tiap rumus regresi, metode pengukuran yang paling tepat, dan bagian tulang mana pada tiap ekstremitas yang memiliki korelasi paling kuat dengan tingkat signifikansi tertinggi untuk dijadikan bahan acuan sebagai parameter estimasi tinggi badan seseorang ketika ditemukan beberapa potongan atau bagian dari tulang ekstremitas. Oleh karena itulah berdasarkan uraian latar belakang tersebut, penulis termotivasi untuk menggarap suatu ulasan tinjauan literatur (literature review) secara sistematis terhadap penelitian terkait, guna mengetahui adanya keragaman hasil akhir dari tiap rumus regresi, metode pengukuran yang paling tepat, serta bagian tulang ekstremitas yang memiliki korelasi dan tingkat signifikansi paling kuat terhadap tinggi badan sebagai teknik rekonstruksi alternatif dalam identifikasi forensik.

\section{METODE PENELITIAN \\ Desain Penelitian}

Jenis penelitian yang digunakan termasuk dalam penelitian kepustakaan atau kajian literatur (literature review, literature research) yang dilakukan dengan mengumpulkan, mengevaluasi, meninjau dan menganalisis dengan kritis gagasan, pengetahuan, maupun temuan yang tertulis pada sebuah literatur yang berorientasi akademik (academic-oriented literature), dan merumuskan kontribusi, baik secara teoritis maupun metodologis terhadap suatu topik yang berkaitan dengan pertanyaan penelitian tentang korelasi panjang tulang ekstremitas terhadap tinggi badan dalam identifikasi forensik. Penelitian kepustakaan ini menggunakan pendekatan tinjauan pustaka secara sistematis (systematic literature review).

\section{Sumber Data}

Data yang dipakai dan digunakan pada penelitian kepustakaan ini adalah data-data sekunder. Data tersebut didapat bukanlah dari pengamatan secara langsung, melainkan dari hasil penelitian yang sudah dikerjakan oleh penelitipeneliti terdahulu. Sumber data sekunder pada penelitian kepustakaan ini adalah artikel asli dari jurnal penelitian yang sudah dipublikasi berkaitan dengan korelasi panjang tulang ekstremitas terhadap tinggi badan dalam identifikasi forensik. Sumber data tersebut dipilih berdasarkan empat aspek yaitu (1) provenance (bukti), yaitu merupakan aspek kredensial seorang penulis dan 
bukti yang mendukung; (2) objectivity (objektifitas), yaitu apakah pandangan dan ide perspektif penulis memiliki nilai guna atau justru sebaliknya; (3) persuasiveness (derajat keyakinan), yaitu apakah penulis penelitian tersebut tergolongan orang yang memiliki rekam jejak baik dan dapat diyakini; dan (4) value (nilai kontribusi), yaitu apakah argumen penulis mampu meyakinkan dan memiliki nilai kontribusi terhadap penelitian lain yang sejenis secara signifikan.

\section{Kriteria Inklusi dan Eksklusi}

Penelusuran literatur berupa artikel ilmiah yang dipublikasi pada mesin pencari google scholar dan sciencedirect.com menggunakan kata kunci yang telah dipilih, yakni: extremity bone length and stature atau panjang tulang ekstremitas dan tinggi badan. Artikel ilmiah atau jurnal yang sesuai dengan kriteria inklusi dan eksklusi tersebut dipilih untuk kemudian dianalisis. Dalam memudahkan penyaringan terhadap kriteria inklusi, maka digunakanlah sebuah instrumen teknik fitur custom range, sort by relevance, dan mencentang pilihan include patents and citations pada mesin pencari secara otomatis. Telaah literatur ini menggunakan jurnal-jurnal yang perlu memenuhi beberapa kriteria, diantaranya diterbitkan pada rentang tahun 2013-2020 yang menggunakan Bahasa Indonesia dan Bahasa Inggris, jenis artikel penelitian asli/orisinal (original article), dan tersedia dalam full-text (teks penuh) berformat .pdf dengan tema jurnal mengenai korelasi panjang tulang ekstremitas terhadap tinggi badan manusia.
Sedangkan penyaringan kriteria eksklusi dilakukan dengan menggunakan instrumen teknik SPIDER (Sample, Phenomenon of Interest, Design, Evaluation, Research Type), penggunaan teknik ini karena menyesuaikan dengan jenis penelitian kualitatif. Berdasarkan teknik tersebut, artikel yang akan dikeluarkan dari penelitian ini jika terdapat kriteria yang tidak koheren, diantaranya sampel penelitian yang tidak menggunakan manusia, fenomena penelitian yang diluar bidang anatomi dan antropologi forensik mengenai: korelasi panjang tulang ekstremitas terhadap tinggi badan, desain penelitian bukan analisis korelatif metode crosssectional, jurnal yang berjenis systematic review, serta tipe penelitian yang bukan kuantitatif.

\section{Prosedur Pengumpulan Literatur}

Proses pengumpulan literatur dan penelusuran data dilakukan dengan menggunakan protokol PRISMA (Preferred Reporting Item for Systematic Reviews and MetaAnalyses) dalam 5 (lima) tahapan, yaitu (1) mendefinisikan kriteria kelayakan literatur dengan kriteria inklusi; (2) mendefinisikan sumber informasi dengan memaparkan pencarian literatur; (3) pemilihan literatur dengan kata kunci, eksplorasi pemilihan judul, abstrak hingga keseluruhan jurnal, kemudian mengkaji kembali dengan melihat kriteria inklusi; (4) pengumpulan data secara manual (nama peneliti, judul penelitian, tahun terbit, negara, metode, hingga ringkasan hasil temuan); (5) pemilihan item data dari jurnal yang terpilih. Ditemukan 31.450 jurnal penelitian yang sesuai 
dengan kata kunci tersebut. Sebanyak 13.385 dari jurnal yang ditemukan sesuai kata kunci tersebut dilakukan penyaringan cepat, kemudian sebanyak 13.323 jurnal dieksklusi karena tidak sesuai dengan tema berdasarkan judul penelitian. Assesment dan penilaian kelayakan secara mendalam dilakukan terhadap 62 jurnal yang tersedia full-text. Jurnal yang tidak sesuai dengan kriteria inklusi dan terduplikasi dilakukan eksklusi pada sebanyak 37 jurnal, sehingga didapatkan 25 jurnal full-text yang paling relevan untuk direview.

\section{Analisis Penilaian Kualitas Data (Quality Assesment)}

Dalam penulisan telaah menggunakan metode Systematic Literature Review (SLR), setiap data yang ditemukan saat pencarian, akan dievaluasi berdasarkan pertanyaan yang sesuai dengan kriteria penilaian kualitas (Quality Assesment) sebagai berikut:

1) QA1. Apakah rentang waktu jurnal yang diterbitkan maksimal 7 tahun terakhir (2013-2020) ?

2) QA2. Apakah jurnal menggunakan Bahasa Indonesia dan atau Bahasa Inggris?

3) QA3. Apakah jurnal merupakan jenis artikel penelitian asli/orisinal (bukan artikel review)?

4) QA4. Apakah jurnal tersedia dalam format .pdf?

5) QA5. Apakah jurnal tersedia teks secara penuh (full-text) dan dapat diunduh?

6) QA6. Apakah tema jurnal memiliki relevansi terhadap penelitian korelasi panjang tulang ekstremitas terhadap tinggi badan?

Dari masing-masing jurnal literatur, akan diberikan nilai jawaban seperti dibawah ini untuk setiap pertanyaan diatas:

1) $Y$ (Ya): untuk jurnal literatur yang memenuhi kriteria inklusi seperti pertanyaan yang diajukan.

2) $\mathrm{T}$ (Tidak): untuk jurnal literatur yang tidak memenuhi kriteria inklusi seperti pertanyaan yang diajukan.

\section{Sintesis Data}

Sintesis literature review ini menggunakan metode naratif dengan cara mengelompokkan semua datadata hasil ekstraksi yang berjenis sama dan sesuai dengan hasil yang diukur untuk menjawab tujuan.

Jurnal ataupun literatur penelitian yang sesuai dengan semua kriteria inklusi tersebut kemudian dikumpulkan dan disusun sebuah ringkasan jurnal yang meliputi beberapa komponen diantaranya nama peneliti, judul penelitian, tahun terbit jurnal, negara penelitian, metode penelitian yang digunakan, dan temuan atau ringkasan hasil. Ringkasan hasil penelitian dari setiap jurnal tersebut kemudian diurutkan sesuai alfabet dan tahun penerbitan jurnal yang sesuai dengan format tersebut diatas.

Analisis jurnal atau literatur penelitian secara mendalam dilakukan dengan membaca abstrak dan full-text jurnal secara cermat, kemudian dibuatlah sebuah ringkasan untuk dianalisis sesuai dengan isi yang tertulis pada tujuan penelitian 
dan hasil ataupun temuan penelitian. Analisis tersebut menggunakan analisis isi jurnal, kemudian dilakukan penandaan terhadap isi jurnal yang sedang ditinjau dengan menggunakan kategori yang sesuai dengan penelitian. Semua data yang telah terkumpul kemudian dianalisis persamaan dan perbedaannya, kelebihan dan kekurangannya, lalu dibahas secara mendalam untuk menarik sebuah kesimpulan penelitian.

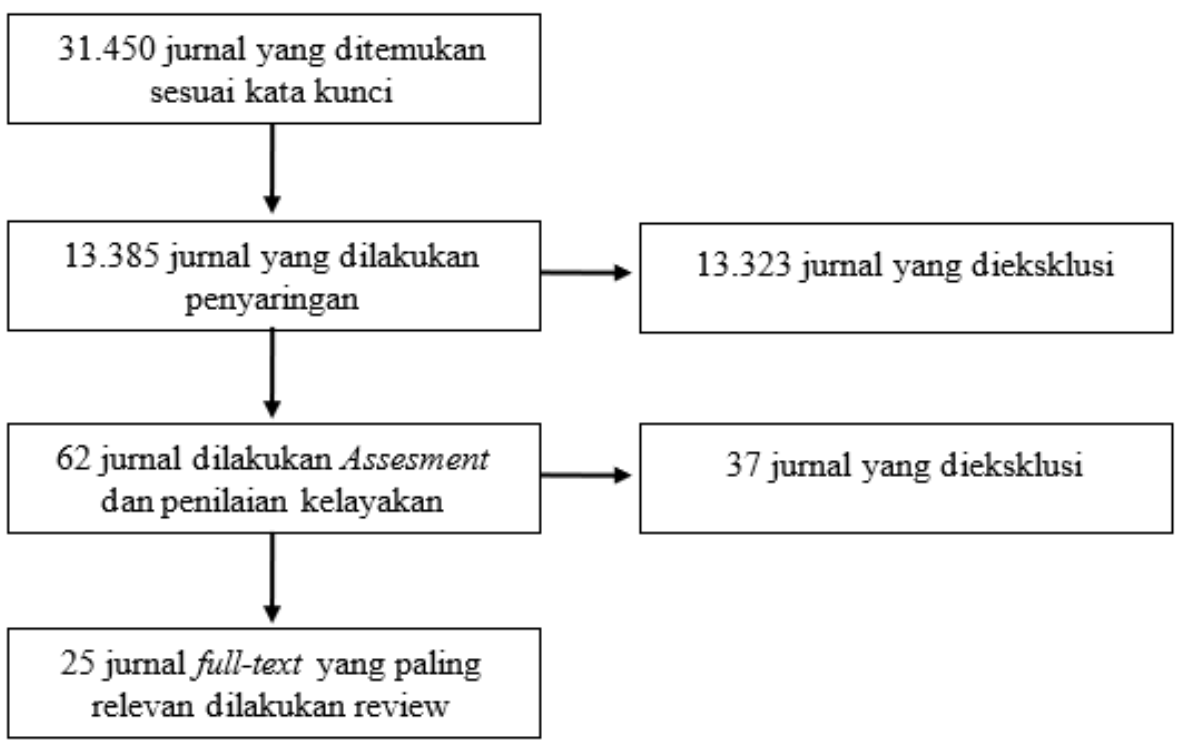

Gambar 1. Diagram Alur Review Jurnal

\section{HASIL DAN PEMBAHASAN \\ Pembahasan Korelasi Panjang Tulang Ekstremitas dengan Tinggi Badan}

Secara keseluruhan, semua hasil penelitian menunjukkan bahwa terdapat korelasi dan hubungan yang sangat bermakna antara panjang tulang-tulang penyusun ekstremitas tersebut dengan tinggi badan. Hubungan ini ditandai dengan nilai koefisien korelasi yang mengindikasikan adanya tingkatan kekuatan hubungan antara panjang komponen tulang ekstremitas terhadap tinggi badan. Tiap komponen tulang penyusun ekstremitas tersebut memiliki kekuatan yang beragam. Dari hasil penelitian yang sebelumnya pernah dilakukan pada ekstremitas atas, terlihat bahwa terdapat 10 dari 17 jurnal penelitian yang menunjukkan korelasi kuat dan sangat kuat antara panjang lengan bawah terhadap tinggi badan yang notabene disusun atas tulang radius dan ulna, jika dipersentasekan yaitu sebesar 58,8\%, sedangkan sisanya adalah 5 jurnal mengenai lengan atas atau panjang tulang humerus yaitu sebesar $29,4 \%$, dan 2 jurnal mengenai panjang tangan yaitu sebesar 11,8\%. Begitupula dengan komponen tulang ekstremitas bawah, dari beberapa hasil penelitian yang pernah dilakukan dapat terlihat bahwa terdapat sebanyak 4 dari 9 jurnal penelitian yang menunjukkan korelasi kuat dan sangat kuat antara panjang tulang tibia dan fibula 
terhadap tinggi badan, jika dipersentasekan yaitu sebesar 44,5\%, sedangkan sisanya adalah 3 jurnal mengenai panjang tulang femur yaitu sebesar 33,3\%, dan 2 jurnal mengenai panjang kaki yaitu sebesar $22,2 \%$.

Dari gambaran persentase tersebut, dapat diketahui bahwa panjang lengan bawah yang disusun oleh tulang radius dan ulna pada ekstremitas atas, serta panjang tulang tibia dan fibula pada ekstremitas bawah memiliki persentase terbesar dan tertinggi dibandingkan dengan komponen tulang lain di ekstremitas manusia. Memang beberapa tulang manusia memiliki karakteristik yang hampir sama, salah satunya adalah antara tulang radius dengan tulang tibia, dan tulang ulna dengan tulang fibula. Sehingga hal ini dapat dijadikan dasar acuan ketika dihadapkan dengan pilihan beberapa penemuan potongan tubuh ataupun bagian-bagian tulang tertentu agar mendapatkan hasil yang lebih akurat dan meminimalisir adanya kekeliruan dalam mengestimasi tinggi badan seseorang.

Pada dasarnya, semua komponen tulang ekstremitas tersebut memiliki hubungan dan korelasi yang bermakna terhadap tinggi badan, walaupun dengan besar kekuatan korelasi yang beraneka ragam. Fenomena ini sesuai dengan konsep alometri yang menunjukkan bahwa tulang ekstremitas tersebut memiliki proporsi yang linear dan konstan terhadap tinggi badan. Hal ini dikarenakan oleh tulang-tulang penyusun ekstremitas tersebut merupakan tulang-tulang panjang yang tumbuh dan berkembang bersamaan dengan tulang lain yang menyusun tinggi badan, artinya jika tulang-tulang ekstremitas tersebut bertambah panjang, maka tubuh manusia juga secara otomatis akan semakin tinggi, begitu pula sebaliknya. Walaupun rasio setiap jenis tulang tersebut bergantung dan terikat pada umur, jenis kelamin, dan ras atau suku bangsa tertentu, namun secara umum konsep teori alometri tulang ini dapat digunakan pada setiap jenis kelamin dan suku.[9] Jika seandainya belum ditemukan basis data rumus regresi ataupun belum pernah dilakukannya suatu penelitian terhadap suatu suku tertentu, maka dapat menggunakan rumus regresi yang paling mendekati rumpun suku tersebut untuk menghindari variasi yang terlalu mencolok dan timpang. Estimasi tinggi badan tersebut dengan menggunakan tulang panjang haruslah mempertimbangkan dan memperhatikan variasi-variasi tersebut. Oleh karena itulah, penting untuk dilakukan penelitian dan menciptakan rumus regresi yang secara spesifik diturunkan pada populasi tertentu agar kemudian dijadikan sebuah basis data tiap suku yang ada di daerah tertentu dan dapat menjadi acuan ketika ditemukan kasus yang memerlukan data tinggi badan seseorang.

\section{Pembahasan Perbedaan Hasil Akhir Rumus Regresi}

Setiap tulang ekstremitas memiliki kekuatan korelasi dan tingkat signifikansi yang beragam terhadap tinggi badan antara satu dengan yang lainnya. Dalam mengestimasi tinggi badan tersebut dapat diprediksi menggunakan metode matematis yaitu dengan menghitung hasil akhir rumus regresi. Banyak penelitian menunjukkan 
bahwa rumus regresi yang menggunakan kombinasi lebih dari satu tulang panjang ekstremitas akan menghasilkan tingkat akurasi yang lebih baik dalam mengestimasi tinggi badan dibandingkan dengan hanya menggunakan satu tulang ekstremitas saja.[10] Dalam beberapa kepustakaan yang pernah dipublikasikan, telah dikenal rumusrumus regresi untuk mengestimasi tinggi badan. Sebagian rumus tersebut bukan berasal dari penelitian yang dilakukan terhadap populasi ataupun penduduk Indonesia seperti rumus Trotter-Glesser, rumus Stevenson, rumus Neumann, dan lainnya. Sedangkan rumus-rumus yang berasal dari penelitian yang dilakukan terhadap populasi ataupun penduduk Indonesia diantaranya adalah rumus Toto Hermanto, rumus Antropologi Ragawi UGM, rumus Martiana, dan rumus lainnya. Setiap rumus tersebut memiliki bentuk formulasi yang sangat beragam antara satu dengan yang lainnya dan begitu pula dengan hasil akhir ketika menggunakan rumus tersebut.

Perbedaan hasil akhir atau selisih antara tinggi badan sebenarnya dengan tinggi badan berdasarkan hasil perhitungan rumus regresi dapat terjadi dan dipengaruhi oleh pelbagai macam faktor yang tidak mampu dikontrol pada setiap penelitian yang dilakukan. Faktor tersebut berkaitan dengan perbedaan postur tinggi badan setiap orang, termasuk tinggi badan subjek yang menjadi sampel dan dilakukan penelitian untuk mendapatkan suatu rumus regresi. Faktor yang memengaruhi tersebut terdiri dari faktor internal dan ekstrenal. Faktor internal diantaranya adalah perbedaan secara herediter (genetik, usia, dan jenis kelamin subjek), hingga hormonal. Sedangkan faktor eksternal diantaranya adalah gizi dan aktivitas fisik yang dilakukan oleh subjek penelitian. terkait hal tersebut, penting bagi seorang peneliti memperhatikan penetapan kriteria inklusi terhadap populasi penelitian yang akan diambil menjadi bagian dari sampel. Hal ini tentu saja akan memengaruhi kualitas hasil dan akurasi dari suatu rumus regresi yang didapatkan.

Faktor lainnya disebabkan karena perbedaan ras atau etnis antara populasi yang menjadi subjek penelitian dengan ras atau etnis jenazah yang akan dilakukan pengukuran. Setiap populasi tentunya memiliki tolak ukur dan besaran konstanta yang berbeda-beda, oleh karena itulah penting untuk melakukan penelitian di beberapa populasi dari latar belakang atau etnis yang belum pernah dilakukan penelitian sama sekali. Hal ini bertujuan agar dapat ditemukan sebuah rumus regresi yang dapat mengestimasi tinggi badan pada populasi tersebut secara spesifik sekaligus menambah basis data di bidang antropologi forensik. Namun, sebelum penelitian dilakukan pada semua populasi dan rumus regresi belum ditemukan, maka dapat digunakan populasi, ras ataupun etnis yang paling mendekati persamaan populasi tersebut. Di Indonesia khususnya dapat menggunakan rumus regresi yang pernah dilakukan dan berasal dari penduduk Indonesia, seperti rumus Toto Hermanto, rumus Antropologi Ragawi UGM, rumus Martiana, dan rumus lainnya. Faktor lain juga dapat disebabkan karena perbedaan selisih antara hasil 
pengukuran pertama, kedua, maupun kesekian kalinya yang dapat terjadi karena pelbagai hal. Oleh karena itulah melakukan pengulangan dalam penelitian ini sangat penting untuk memperkecil kemungkinan bias dan variasi hasil, semakin banyak pengulangan yang dilakukan maka akan semakin baik. Jumlah populasi dan sampel yang menjadi subjek penelitian pun memengaruhi kualitas dan keakuratan suatu rumus regresi, sehingga sangat penting bagi peneliti untuk memperhatikan hal tersebut agar mengurangi kemungkinan risiko bias dan kesalahan dalam hasil penghitungan akhir dari rumus regresi.

\section{Pembahasan Pendekatan Metode Pengukuran Panjang Tulang}

Setiap penelitian yang mengukur panjang tulang ekstremitas untuk mencari hubungannya dengan tinggi badan dilakukan dengan dua cara, yaitu manual secara perkutaneus dan dengan cara menggunakan Computed Tomography (CT). Berdasarkan jurnal yang sudah dilakukan review, mayoritas penelitian dilakukan dengan menggunakan cara manual, tulang panjang tersebut diukur secara langsung atau perkutaneus. Sebanyak 24 jurnal dari seluruh jurnal yang dilakukan review, jika dipersentasekan yaitu sebesar 96\% menggunakan pengukuran secara perkutaneus. Sedangkan sebagian kecil saja yang melakukan pengukuran panjang tulang ekstremitas dengan menggunakan bantuan CT. Hanya ada 1 jurnal yang ditulis oleh Qun Zhang, dkk menggunakan metode Post-Mortem Computed Tomography (PMCT), jika dipersentasekan yaitu hanya $4 \%$ dari keseluruhan jurnal yang dilakukan review.

Banyak hal yang menjadi kelemahan dengan menggunakan teknologi pencitraan ini, salah satunya adalah bias hasil pengukuran antara panjang sebenarnya dengan hasil CT dapat berbeda. Hal ini dikarenakan pengukuran tersebut tidak dilakukan secara langsung terhadap tulang panjang, melainkan menggunakan alat-alat diagnostik canggih. Teknik pemindaian ini bahkan juga pernah dipakai dalam proses otopsi virtual sejak tahun 1977 dan terus menerus berkembang hingga sekarang. Namun pada tahun 1990 sudah menggunakan pencitraan radiografi 3 (tiga) dimensi dalam pemeriksaan post-mortem. Pada satu sisi, teknologi pencitraan ini sangat baik untuk menegakkan diagnosis dalam kepentingan klinis, namun tidak dalam kepentingan medikolegal. Hal-hal yang menjadi kelemahan dan perlu dipertimbangkan dalam menggunakan teknologi pencitraan dalam mengukur panjang tulang ekstremitas adalah sebagai berikut:

a. Potensi bias yang sangat besar dalam melakukan pengukuran dengan menggunakan teknologi pencitraan ini dibandingkan dengan melakukan pengukuran secara langsung. Hal ini dikarenakan gambar hasil pencitraan tersebut belum tentu sesuai dengan panjang asli tulang atau bagian tubuh yang hendak dilakukan pengukuran. Gambar hasil pencitraan tersebut pula membutuhkan skala baku tertentu agar dapat sesuai dengan panjang asli tulang atau bagian tubuh yang 
diukur, namun saat ini belum ada ketentuan maupun kesepakatan mengenai skala tersebut. Potensi bias yang lain juga dapat disebabkan oleh operator, kesalahan arah, peletakkan, hingga artefak lain yang mungkin ikut terdokumentasi.

b. Ketersediaan alat yang tidak memadai, apalagi jika ditemukan sebuah tulang ataupun potongan jenazah yang berada di daerah terpencil. Hal ini akan menghambat proses identifikasi itu sendiri. Sedangkan jika melakukan pengukuran secara perkutaneus dapat dilakukan secara langsung walaupun di medan yang sulit dan terpencil sekalipun.

c. Permasalahan biaya yang lebih besar untuk melakukan pengukuran menggunakan teknologi pencitraan ini jika dibandingkan dengan mengukur panjang tulang atau bagian ekstremitas secara perkutaneus.

d. Permasalahan waktu yang dibutuhkan lebih lama untuk melakukan pengukuran menggunakan alat-alat pencitraan jika dibandingkan dengan mengukur panjang tulang atau bagian tubuh tertentu secara perkutaneus. Hasil estimasi tinggi badan seseorang tidak dapat diketahui pada saat itu juga secara langsung.

Kelemahan-kelemahan tersebut perlu menjadi pertimbangan dalam melakukan pengukuran panjang tulang ekstremitas, baik dalam melakukan penelitian maupun dalam melakukan pengumpulan data untuk mencari identitas seseorang. Pilihan terbaik adalah mengukur panjang tulang ataupun potongan tubuh manusia tersebut secara langsung dengan perkutaneus. Hal ini bertujuan agar mendapatkan hasil yang lebih akurat dan meminimalisir potensi bias. Pengukuran secara perkutaneus dilakukan dari satu titik hingga ke titik atau struktur tertentu secara anatomis.

\section{KESIMPULAN}

Berdasarkan penelitian yang sudah dilakukan, diketahui bahwa:

1. Panjang lengan bawah yang disusun oleh tulang radius dan ulna pada ekstremitas atas, serta panjang tulang tibia dan fibula pada ekstremitas bawah memiliki persentase terbesar dan tertinggi dibandingkan dengan komponen tulang lain di ekstremitas manusia.

2. Perbedaan hasil akhir atau selisih antara tinggi badan sebenarnya dengan tinggi badan berdasarkan hasil perhitungan rumus regresi dapat terjadi dan dipengaruhi oleh pelbagai macam faktor yang tidak mampu dikontrol pada setiap penelitian yang dilakukan. Hal ini diduga dipengaruhi ras dan struktur tulang yang sifatnya subjektif.

3. Di Indonesia khususnya dapat menggunakan rumus regresi yang pernah dilakukan dan berasal dari penduduk Indonesia, seperti rumus Toto Hermanto, rumus Antropologi 
Ragawi UGM, rumus Martiana, dan rumus lainnya.

4. Hasil pengukuran antara panjang sebenarnya dengan metode imaging/pencitraan diduga memiliki bias selisih, sehingga pengukuran panjang secara perkutaneus lebih baik dan disarankan agar langsung mendapatkan ukuran yang anatomis.

\section{UCAPAN TERIMA KASIH}

Terima kasih kami tujukan kepada Fakultas Kedokteran Universitas Palangka Raya dan Instalasi Kedokteran Forensik RSUD dr. Doris Sylvanus Palangka Raya yang telah menyediakan fasilitas pendukung untuk menyelesaikan studi ini.

\section{DAFTAR PUSTAKA}

[1] United Nations Office on Drugs and Crime. Global Study on Homicide; Executive Summary. 2019.

[2] Badan Pusat Statistik. Statistik Kriminal Tahun 2018. 2019. 37-39 p.

[3] Badan Pusat Statistik. Provinsi Kalimantan Tengah Dalam Angka Tahun 2018. 2019.

[4] Hoediyanto HA. Buku Ajar Ilmu Kedokteran Forensik dan Medikolegal. Surabaya: Departemen Ilmu Kedokteran Forensik dan Medikolegal Fakultas Kedokteran Universitas Airlangga. 2012.

[5] Devison RJ. Penentuan Tinggi Badan Berdasarkan Panjang Lengan Bawah. Medan: Fakultas Kedokteran Universitas Sumatera Utara. 2009.
[6] Budiyanto, dkk. Ilmu kedokteran Forensik Fakultas kedokteran Universitas Indonesia Edisi Kedua. Jakarta: Binarupa Aksara. 2007: 1,197202.

[7] Maulina Nora, dkk. Estimasi Tinggi Badan Berdasarkan Tulang Femur Perkutan Pada Mahasiswa Suku Aceh Universitas Malikussaleh. Banda Aceh: Fakultas Kedokteran Universitas Malikussaleh. 2015.

[8] Putri INW. Korelasi Panjang Tulang Jari Telunjuk Tangan (Digiti II) Terhadap Tinggi Badan Pria Dewasa Suku Bali dan Suku Batak di Kecamatan Tanjung Senang Bandar Lampung [Skripsi]. Lampung: Fakultas Kedokteran Universitas Lampung. 2017.

[9] Borkar MP. Estimation of height from the length of humerus in western region of Maharashtra. International Journal of Research in Medical Sciences. 2014; 2 (2).

[10] Pal DC, Datta AK. Estimation of stature from radius length in living adult Bengali males. Indian Journal of Basic and Applied Medical Research. 2014; 3 (2). 